\title{
部会報 告
}

\section{$>$ 関東・東京部会（第27回）}

\author{
日 時 昭和 55 年 10 月 18 月 (土)，19日.(日) \\ 会 場·軽井沢町中央公民会館 \\ 特別講演
}

80 年代の医療之医療技術者の役割

厚生連佐久総合病院院長 若月俊一先生

\section{シンポジウム}

群馬県下における消化管撮影の現状と今後の課題

座長，富沢俊男君（富沢内科小照科病院）

\section{1. 胃ルチン検查の一手技の検討}

群馬県国立高崎病院 ○金井 進

胃ルチン検查経口法では四代撮影検査方法を基本とす ると共に，最大描写域，所用最短時間，苦痛不安感等む 考虑して行わなくてはならない事は最良のテクニックを 施し最大の情報を提供する事价ある。ここでは胃体上部 後壁二重造影を沉用装置X線テレビにより鉤状胃，牛角 胃, 瀑状胃の天板角度の被写体角度加ら見ての一手技を 検討した．撮影方法は半卧立第四斜位，半立卧位の二重 造影像で，天板角度15度位が主で被写体軸を中心とした 角度 5〜10 度が主とされた沉例を示す。異常陰影に対し, 部位的にも二方向以上より撮影される事が辺縁の描写と 異常区域を示す事にもなり読影効果を増す。バリウム， 発泡剤の用法と，各胃形の撮影体位変換を示す。

\section{2. 群馬県下における消化管撮影の現状と今後の課題} （消化管撮影にむける造影剤の検討）

\section{群馬県立前橋病院 ○平野邦弘}

〔目的】，消化管疾患の㟝断はX線写真化依存する比率 は大きい。良いX線写真を撮影することは蜘患の早期発

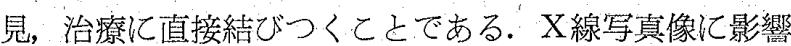
を与える因子の内，今回，市販されている 4 社，粉末造 影郕 6 製品を単品，混合において基整的な実験をおてな った.

〔方法】アンケート集計結果にあとづき粉末造影剤 6 雑品の単品時，同社 2 製品混合時の(1)粘度，(2)沈降性， (3)耐酸性, (4)付着性, (5)消泡性について調べた。

〔結論・考祭〕X線写真による消化管疾㭧の彰断にお 认て造影剂の選定は大きい子考えられる。特に胃液酸度 の影響は強く, 我々の行うスクリーニング検査に於して
は造影剤の基本的な特性を理解し，臨床に適した選定を するととが必要に思われる。

\section{3. 胃集団検診の立場から特に被曝軽減を考慮して}

(財)群馬県対がん協会・O桜井德闭

〔目的门罥集検江於ける被曝線量功とかく問題視され ている昨今，当協会で平素稼動している検診車について 被曝線量を測定し，併せて比較検討したので報告する。

「方法】当協会の 4 車種の胃集検車について I.I. 之る ラ一, 從来の $\mathrm{PO}$ 螢光板と稀土類營光板, フィル夕附加 によるもの等の 3 点について測定し，比較検討を行っ た.

〔結果】：線量を測定した結果 I.I. はミラーに比し 6 枚 撮影 +30 秒透視で $1 / 28$, 稀土類については PO 型汇比し 1/3，また，装置によっては附加フィルタによりかなり の被曝線量軽減に結びついた。，今後，胃集検事業を発展 させるにはより搒断価値の高い写真を得る為の努力は 勿諭，胃癌発見率を低下させるととなく無用な被曝に対 する対策を充分考える必要がある。

\section{4. 群馬県下における消化管撮影と今後の課題 （消化管撮影における感材との関係）}

日本電信電㖕公社 高崎健康管理所 ○小材幸二

〔目的】県下の消化管撮影飞おいてはレギュラータイ プの使用が大半を占めているのが現状である. そこでレ ギュラータイプとオルンタイプ有意差があるのか, 臨 床に近认状態での比較検討を行った。

〔方法] MTF; RMS 粒状度は JIS 規格水ファント ム，.. 主観的評価は magen ファントムを使用し，管電圧 $90 \mathrm{kVp}$ 一定にて实験を行った.

〔結果及び考察】MTF，RMS 粒状度とも，レギュラ ータイプ，オルソタイプに打いて顕著な差が認められず,

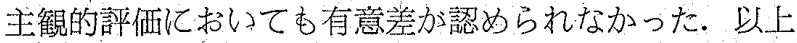
今回の実験結果より，画質的にさほど差がないならば， 被曝線量を低减できるオルソタイプの使用も十分考慮す る必要があると思われる。

5. 消化管撮影における装置との関係

群馬大学医学部附属病院 中央放射線部

$$
\text { 香山二郎 }
$$

〔目的〕群馬罧内の消化管撮影装置の現状調查と，ア 